\title{
African Instituted Churches in Southern Africa: Paragons of Regional Integration? ${ }^{1}$
}

\section{Ezra Chitando*}

\begin{abstract}
While the role of Christian churches in the struggle for liberation in Southern Africa has been acknowledged, most writers have glossed over the importance of religion to regional integration. Most studies on the churches tend to be limited to specific countries and thus overlook the transnational connections. This study explores the activities of African Instituted Churches (AICs) in Southern Africa. It examines the emphasis of some Apostolic churches on black economic empowerment and outlines their dominance in the informal sector. It argues that AIC members are actively involved in cross-border trading and have formed transnational support systems. Fellow believers in Botswana, South Africa and Mozambique, for example, host AIC traders from Zimbabwe. This study maintains that whilst politicians and technocrats on the continent are still debating issues concerning indigenisation, the NEPAD initiative and other strategies for integration, AICs are already implementing these ideas. The study recognises the importance of religion to Southern Africa and analyses the role of spirituality in the quest for total liberation in the region.
\end{abstract}

\section{Résumé}

Bien que le rôle des églises chrétiennes dans la lutte pour la libération de l'Afrique australe ait été reconnu, la plupart des écrivains ont négligé l'importance de la religion dans le processus d'intégration régionale. La plupart des études ont tendance à se cantonner à des pays spécifiques, en survolant les connexions transnationales. Cet article s'intéresse aux activités des Eglises à Institution Africaine (AIC) d'Afrique Australe. Il étudie l'importance que certaines églises apostoliques accordent à la notion de black economic empowerment (émancipation économique des noirs) et souligne la prédominance de celles-ci dans le secteur informel. Cette analyse démontre que

* University of Zimbabwe, Zimbabwe. 
les membres des AIC sont activement impliqués dans le commerce transfrontalier et ont constitué des systèmes de soutien transnationaux. Par exemple, les disciples du Botswana, d'Afrique du Sud et du Mozambique hébergent des commerçants AIC du Zimbabwe. Cette étude affirme que pendant que les hommes politiques et les technocrates débattent de questions relatives au processus d'indigénéisation, de l'initiative du NEPAD et autres stratégies d'intégration, les AIC, elles, sont déjà en train d'appliquer ces principes. Cette étude reconnaît l'importance de la religion en Afrique Australe et analyse le rôle de la spiritualité dans le projet de libération totale de cette région.

\section{Introduction}

Regional and continental integration have become buzzwords within African political and economic discourses. Underpinning the initiative to have the African Union is the conviction that harnessing resources will bring economic and social benefits to member states. The spirit of cooperation is also indelibly imprinted on the collective consciousness of African peoples. As one African proverb puts it, "When spider webs unite, they can trap a lion.” The ideal of Pan-Africanism has also galvanised nations to strive for unity and cooperation across the continent. It is envisaged that, with gritted determination and singleness of purpose, Africa shall finally shrug off the "Dark Continent" image and experience remarkable transformation in the postcolonial period.

Regional bodies such as the Southern African Development Community (SADC) have emerged from this drive to attain integration. A number of studies have been conducted on different aspects of this process. These include trade and investment in Southern Africa (Chipeta 1998), labour and migration (Sachikonye 1998), as well as migration and development (Matlosa 2001). Such studies have shown the potential of Southern African countries to bring better living standards to their citizens. However, the religious dimension within the quest for integration has been consistently overlooked. This has had the effect of reducing discussions on regional cooperation to purely economic and materialistic issues. This study seeks to correct such an approach by highlighting the importance of spirituality in African life.

This study acknowledges the role of religion in social transformation in Southern Africa (Walsh and Kaufmann 1999). Using the example of African Instituted Churches (AICs), the study argues that religion plays a significant role in bringing people of the region together. In the first section, the study outlines the emergence of AICs, paying particular attention to their emphasis on black independence in all sectors 
of life. The second section highlights the importance of religious links for some cross-border traders from Zimbabwe. It illustrates how a shared faith has acted as the basis for mutual support for believers coming from different countries. The third section argues that AICs provide a useful model of grassroots cooperation within the region. In conclusion, the study urges planners to recognise the continued vibrancy of spirituality within Southern Africa. As technological sophistication increases, it will become tempting to dismiss the religious approach to reality as a relic from the past. This study maintains that the region can use religion as one of its greatest assets in striving for health and prosperity.

\section{Domesticating Christianity: The Rise of African Independent Churches}

Before a description of the contemporary activities of the AICs can be undertaken, it is necessary to provide a brief background of their emergence in the region. This topic has attracted the attention of scholars from diverse disciplines. Numerous debates have emerged regarding the causative factors, typology and terminology (Anderson 2000: 8). A number of terms, including, 'African Independent Churches', 'African Initiated Churches', 'African Indigenous Churches' and 'African International Churches' have been used interchangeably to characterise this phenomenon. These labels strive to capture the African initiative in Christian mission. They also seek to distinguish AICs from the 'mainstream' or 'mission-derived' churches such as the Catholics, Anglicans, Methodists and others. A detailed analysis of the terminology goes beyond the purview of this study.

The remarkable success of Western Christian missionaries in Africa in the late nineteenth and early twentieth centuries has been well documented (Isichei 1995). Through the translation of scriptures into African languages, provision of social services and other strategies, Christianity succeeded in capturing the African imagination. Many Africans converted to Christianity, resulting in a significant shift in its centre of gravity to the two-thirds world. The notion of Christianity as the white person's religion was profoundly challenged as Africans embraced the faith in large numbers.

The mass movement of Africans to Christianity was, however, not without problems. In Southern Africa, Africans experienced racism in 
the mission churches. Many white Christians discriminated against blacks, regarding them as junior brothers and sisters. This refusal by whites to accept blacks as equals is one of the main reasons for the rise of AICs. Africans also felt that the style of worship in the mission churches was too static and they endeavoured to implement a lively style. The demonisation of most African beliefs and practices by the missionaries also encouraged Africans to seek alternative havens of belonging. Lack of leadership opportunities, personal ambitions, theological controversies and other factors resulted in the rapid multiplication of AICs (Daneel 1987).

By the 1920s, AICs had become a significant feature of the religious landscape in Southern Africa. Africans had taken it upon themselves to couch the Christian message in African idiom. Rejecting the verdict of most foreign missionaries that African culture was heathen and in need of cleansing by the gospel, many founders of AICs actively sought to appropriate indigenous traditions in their movements. Within the $\mathrm{Zi}$ onist churches, namely those that yearned for the holy city and were moved by the Holy Spirit, a creative adaptation of African Traditional Religions (ATRs) was consciously sought. Most of these founders had little formal education but they succeeded in unleashing a powerful movement that decisively changed the face of Christianity. In the hands of energetic spirit-filled prophets, the Christian message underwent radical interpretation and transformation.

Some founders of AICs retained the administrative structures of the Western denominations they had separated from. These churches are often termed 'Ethiopian' and they also had a strong Africanist thrust. Empowered by the passage, "Let Ethiopia hasten to stretch out her hand to God" (Psalm 68:31), Ethiopian churches preached the message of African emancipation in all sectors of life. Ethiopianism should be acknowledged as one of the key guiding ideologies in the struggle for liberation by blacks on the continent and in the Diaspora (Chirenje 1987).

Although AICs were diverse in their beliefs and practices, and continue to be so today, they were all characterised by the desire to allow Africans to express themselves freely in the new religion. Independence from white racism, paternalism and oppression is a salient feature of the AIC movement in Southern Africa. Rejecting the Hamitic myth of perpetual black subservience and inferiority to whites, AICs sought to equip their followers to affirm their dignity and value. Through the 
composition of new songs, reading the scriptures from African standpoints and dramatic healing sessions, AIC prophets repackaged Christianity as an African religion that found resonance with African aspirations. Some scholars in the study of African Christianity have maintained that Christianity has taken an essentially African flavour, a central goal of the AICs (Chitando 2002).

In Zimbabwe, some founders of AICs, like Johane Masowe, had distinctive messages to deliver to the blacks. His Apostolic movement sought to empower blacks economically by challenging them to reject their low status in the racist and oppressive formal sector. This was a response to oppressive legislation that sought to protect white interests during the colonial period. Masowe encouraged his followers to be creative and to find alternative strategies for survival in a stifling environment. They became actively involved in the informal sector, excelling in basket making and metal work (Dillon-Malone 1978). By withdrawing from participating in the highly skewed colonial economy, AICs were undermining the oppressive system.

The emergence of AICs in the region was also tied to the nationalist awakening. Colonial regimes were wary of the brazen confidence of African prophets who asserted the right of blacks to worship openly and unhindered. Many colonial administrators were worried about the spontaneity characterising AICs, rightly fearing that the Holy Spirit could blow in the direction of armed resistance. Prophetic utterances on the integrity of blacks coincided with the nationalist cry that Africa belonged primarily to Africans. Significantly, both the AICs and African nationalism went beyond the narrow confines of colonial boundaries. Both movements were characterised by transnational networks, with nationalists like Joshua Nkomo and Robert Mugabe of Zimbabwe getting their nationalist awakening while in South Africa. Similarly, some AIC founders in Zimbabwe were indebted to South African prophets. The following section seeks to briefly examine the transnational networks that are discernible in the activities of AICs.

\section{Going Forth: AICs in Southern Africa}

The emergence of AICs in Southern Africa is intimately related to the movement of people and ideas within the region. A good example is how AICs in South Africa provided the impetus for the rise of AICs in Zimbabwe, with returning migrant workers founding their own churches. This South African influence can also be detected in the spread of wom- 
en's movements in the mainline churches. Migration within the region preceded colonialism, although the gold mines of South Africa heightened these cross-cultural exchanges. It is also important to note that mutual exchange characterised this interaction, with migrant labourers from within the region influencing the host culture in turn.

David Maxwell (2002: 296-297) has observed that, "The so-called African independent churches had a great propensity to movement, often to the point of its being a defining characteristic." This observation is accurate and stems from the fact that AIC preachers criss-crossed the region with the message of an African spiritual revival. Central to their message was the conviction that the hour of Africa's salvation had come. Unlike the missionaries who interpreted salvation in a trammelling manner, AIC preachers had a holistic understanding of salvation. Africa's salvation entailed total religious, political and economic emancipation. Armed with this message, AICs spread across the region at a pace that surprised missionaries and scholars alike.

Charismatic men and women like Isaiah Shembe in South Africa, Masowe in Zimbabwe, Alice Mulenga Lenshina in Zambia and others felt compelled to spread the gospel to Africans. Highly mobile and propelled by an acute sense of urgency, they called upon Africans to embrace Christianity, but with an African flavour. Masowe Apostles, for example, took a conscious decision to preach across sub-Saharan Africa. Their founder had a clear Africanist agenda where Africa would become the centre from which the message of salvation would go into the world. Similarly, Paul Mwazha formed his African Apostolic Church that sought to project Africa as the new source of salvation history. Where the white missionaries had written off Africa, AIC leaders were becoming the new missionaries to Africa. They disputed the claim of racial superiority by the whites and endeavoured to demonstrate that Africans were spiritually equipped to preach the good news of human liberation. Harvey Cox (1996: 251) rightly notes that, "no one can read their early history without noticing a certain element of rebelliousness against European expressions of the faith, for the founders of these churches were rebels as well as prophets."

Women have played a significant role in the rapid spread of AICs in Southern Africa. Apostolic women in their distinctive white garments and Zionist women in colourful outfits have become an integral part of urban life in the region. It is women who constitute the majority of members within AICs, and they have been central in the emergence of 
transnational networks that have emerged. A number of reasons have been proffered in an effort to explain the dominance of women in AICs. One of the key attractions is the space that has been granted to women in these new religious movements. They are allowed to express themselves fully, and to occupy key offices as prophetesses. Thus:

\begin{abstract}
Africa's new religious movements provide a rich and varied spectrum of women's agency. Religious symbols and practices shape women's perceptions of themselves, their relations with others, their ability to act, and provide strategies for survival and empower and disempower them within the context of their religious and wider communities (Hackett 1995: 262).
\end{abstract}

AIC women constitute a massive evangelising army that has spread this particular brand of Christianity in Southern Africa. As they traverse the region in cross-border trading, these women have carried the message of African self-reliance. Other AIC women have become itinerant preachers, moving from one community to the other. It is through such constant changing of operational zones that AICs have posed a fundamental critique to the inherited colonial boundaries. AICs preach the message of salvation to Africa in her entirety, and pay little attention to imposed borders. In the following section, I seek to highlight how this feature has contributed to regional integration.

\title{
Cords That Cannot Be Broken: AICs and Regional Cooperation
}

When the former colonial masters met at the Berlin Conference in 1884/ 1885, they carved the continent with scant regard to the existing political and cultural boundaries. Close relatives often found themselves in different countries due to the arbitrary nature of the exercise. In some places, communities need to apply for visas to enable them to cross borders and hold traditional rituals at their sacred shrines. AICs have generally refused to endorse the colonial invention, preaching to Africans wherever they are found. As the previous section highlights, AICs have spread throughout the region, cutting across national and ethnic identities. These ties that were formed amongst AICs during the colonial period have been sustained in the postcolonial period.

On the basis of a shared faith, AICs have provided support systems for members from different economic backgrounds and nationalities. In South Africa, for example, AICs have multiple functions, including 
acting as mutual aid societies and supporting small-scale businesses (Oosthuizen 1992). In urban contexts where the traditional family support systems are not always readily available, AICs have played important roles. As healing movements, AICs in Southern Africa have brought together people with diverse identities and have given them a sense of unity. This capacity to build new communities is an important resource that should be utilised in the quest to forge a common African identity. It emerges from the ecumenical nature of AICs.

Although African Christianity inherited the divisive aspect of denominationalism from the missionaries, it has sought to promote ecumenism. Mainline Protestant churches in most countries come together under their National Council of Churches. In Zimbabwe, AICs have an ecumenical organisation called Fambidzano, initiated by the missiologist Inus Daneel. At the continental level, the Organisation of African Instituted Churches (OAIC) seeks to present the collective voice of indigenous churches. It is this ecumenical thrust of AICs that has facilitated the cooperation of members in the informal sector.

Cross-border trading within the SADC region has a long history that precedes colonialism. In the postcolonial period goods and services have moved in various directions, depending on the state of particular national economies. When the economic situation in Zimbabwe deteriorated in the 1990s, there was a marked increase in the volume of crossborder trading. Individuals selling stone sculpture, electrical goods and other items constantly moved between the country and South Africa, Botswana, Mozambique and other countries.

The decision to take up cross-border trading as an alternative survival strategy is in most cases painful and characterised by anxiety. Women in particular have found the patriarchal ideology dominant within the region suffocating (Gaidzanwa 1998). Negative labels and suspicions have accompanied women who have become economically empowered by selling their wares outside the country. As Victor Muzvidziwa (1998) notes, female cross-border traders from Zimbabwe face numerous challenges in their quest to fend for their families. These include xenophobia, sexual exploitation, difficult visa requirements and others. With the shortage of foreign currency in the late 1990s, the continued vibrancy of the sector has been threatened. AIC women traders have used the resources from within religion to strive to overcome these challenges. 
AIC members in host countries have sought to mitigate some of the challenges that Zimbabwean traders face. Since accommodation is one of the major problems that the traders face, AIC members in host countries have often been willing to stay with fellow believers from Zimbabwe. A good example is the close cooperation between members of the Zion Christian Church (ZCC) in South Africa and Zimbabwe. Due to the influence of the South African church in the formation of the Zimbabwean one, strong ties exist between the two AICs. Furthermore, members in both countries often put on distinctive badges that give them a specific identity. Informal traders from the ZCC in Zimbabwe have been well received by fellow believers in South Africa and Botswana.

Access to markets is another daunting challenge that cross-border traders have to negotiate. Due to the experience of AICs in the informal sector, members in host countries induct those coming from outside. Although competition certainly exists, it is clear that contact with fellow believers in a specific trade has enabled Zimbabwean traders to thrive. This spirit of unity amongst believers is cultivated and enhanced at religious gatherings in the different countries. A lot of networking takes place at the various transnational conventions within the region. As with the newer Pentecostal churches, AICs utilise connections that transcend national boundaries. Thus:

The 1980s and ' 90 s have seen the development of an increasingly complex web of transnational Pentecostal networks, where flows of people, money, ideas and images circulate with speed and intensity, defying all attempts to pin them down to any particular source or destination (Corten and Marshall-Fratani 2001:1).

A good example of this form of networking is discernible in the operations of one of the largest AICs in the region, the African Apostolic Church of Paul Mwazha. It holds an annual convention at its sacred site, Guvambwa, in Zimbabwe. It was at Guvambwa that Mwazha had a vision where he was commissioned to be an apostle for the African continent. Over a million pilgrims from all over the region attend this significant event. Preachers from different countries emphasise the centrality of a shared faith and call upon adherents to have a common identity. It is such ideologies that help to foster the spirit of cooperation amongst members of AICs in Southern Africa. 
Periodic retreats to mountains and secluded spaces also equip AIC traders from different countries to share a feeling of belonging. This practice of regular prayer and fasting gives AICs a deep spiritual outlook. Emerging from holy groves and putting on a common white garment, AIC members momentarily obliterate national, ethnic and class distinctions. A fellow believer-a prayer warrior-from Zimbabwe becomes closer than an unbelieving compatriot. Through intense supplication and inspired singing, members of AICs plead for earthly success in the various fields of life. In this quest, nationality plays a secondary role to the common African and black identities. It is as African brothers and sisters that members of AICs approach and treat each other.

The regional integration championed by AICs is based on the need to utilise Christianity in the struggle for black economic empowerment (Chitando 1998). AICs interpret the Christian message as availing abundant life to all Africans, irrespective of their country of origin. Deliverance from spiritual and material poverty and foreign dominance in all spheres of life is a key feature of salvation as it is preached in AICs. In a context where cross-border traders and other Africans operating in the informal sector may be tempted to give up, AICs urge their followers to continue fighting. As forces of globalisation and Economic Structural Adjustment Programmes threaten to liquidate Africans economically, politically and culturally, AICs motivate their members to persevere and subvert these stifling systems. Thus, "Pentecostals conscientize the individual to fight back, to refuse to accept defeat, want, failure and pessimism or negativity"(Kalu 2000:127).

The grassroots cooperation that exists amongst followers of AICs across the region has valuable lessons for proponents of regional and continental integration. Their transnational support systems are effective and emerge from a shared religious ideology. In the ensuing section, I seek to highlight the significance of the AIC model to policy makers in the region. I argue that grassroots communities are marching ahead of planners and politicians in the area of integration.

\section{AICs and Regional Integration: Some Emerging Themes}

AICs in Southern Africa illustrate how ordinary citizens implement various developmental programmes ahead of official pronouncements and declarations of intent. Due to their long history of networking within the region, AICs are already living out the ideal of regional inte- 
gration. While politicians and planners have held consultations on indigenisation, the New Economic Partnership for Africa's Development (NEPAD), the African Renaissance and other initiatives, AICs have already begun to bring these into reality. To make this observation, however, is not to denigrate the value of academic reflections. It is to recognise the fact that the grassroots communities should be allowed to influence policy planning.

Ideological consciousness will be invaluable for the success of regional and continental integration. It is regrettable that in the euphoria of globalisation and the reality of a unipolar world, 'ideology' has become politically incorrect. Although struggles for black liberation from the yoke of slavery and colonialism were based on clearly enunciated ideological principles, economic integration in postcolonial Africa is still expected to occur in an ideological vacuum. AICs provide a helpful model in terms of providing sound ideological principles. President Thabo Mbeki of South Africa has rightly insisted that Africa is fully human. Thus:

An essential and necessary element of the African Renaissance is that we all must take it as our task to encourage she who carries this leaden weight to rebel, to assert the principality of her humanity-the fact that she, in the first instance, is not a beast of burden but a human and African being (Hadland and Rantao 1999:173).

Following the setting up of the African Union, nagging questions remain concerning its operations. Stringent visa requirements and travel restrictions continue to frustrate the movement of people and goods on the continent. Although many nationals from Zambia, Mozambique and Zimbabwe perished during South Africa's liberation struggle, most South Africans have repaid them with xenophobia and condescending labels. While they are willing to embrace white immigrants, many black South Africans loathe immigrants from within the continent. This absence of solidarity has meant that true regional integration has received its greatest support at the level of rhetoric. African political leaders have congratulated each other for initiating lofty philosophical projects that do not reflect the reality on the ground.

AICs may impart valuable insights to those who seek a democratic renaissance in Southern Africa in terms of their insistence on African ownership of resources. As the preceding sections illustrate, founders of AICs proclaimed the gospel of self-reliance and utilisation of African 
resources for the development of her people. As long as Africa's resources are in the hands of foreigners, she will continue to enjoy 'flag' independence, devoid of control of wealth. Although President Robert Mugabe of Zimbabwe has had his radical approach to the land issue demonised due to a number of contradictions, the principles upon which his project is built are commendable. In his pronouncements on the land question, he has consistently evoked a theme emerging from the AICs: Africans should be left to become masters of their own destiny (Mugabe 2001).

The networking amongst AICs in the region shows that considerable steps have been undertaken to achieve integration. As AIC members from Botswana and South Africa share the ritual meal of remembering the sacrificial death of Jesus, they solidify a common African Christian identity. When the Apostolic women in Bulawayo, Zimbabwe's second largest city, trade in large amounts of foreign currency with their sisters from Mozambique, they weave strong bonds that cannot be broken easily. In these little symbolic gestures, AIC members are vividly demonstrating how people within the region can usher in a new era of cooperation.

However, as the region seeks to propel itself into a vibrant zone characterised by democracy, good governance and economic growth, it finds itself facing the menace of HIV/AIDS. The region is at the epicentre of this pandemic, which threatens to reverse all the gains that have been achieved so far. South Africa, Botswana and Zimbabwe are amongst some of the worst affected countries in the world, and the high death rate has generated a lot of despair. The AIC message of healing, compassion and hope becomes particularly relevant in this context. Amidst so much suffering and death, hope usually becomes the first casualty. The AIC prophetic message of hope may resurrect and recharge communities to meet the challenge (Okeyere-Manu 2003).

Despite the challenges posed by HIV/AIDS, the informal sector has continued to be the arena where much creativity has gone on. Policy planners in the region need to take this sector seriously. In many instances, proponents of regional integration have operated with grandiose projects in mind. However, small to medium scale projects across the region may be more beneficial to ordinary citizens. Of special significance should be projects that target the empowerment of women. Although women in the region heave under the weight of oppressive cultural practices, they have demonstrated remarkable resilience and 
tenacity. AIC female cross-border traders in Zimbabwe have increased the disposable income of their families. It is therefore important to support such women if the ideal of liberating women is to be achieved.

Technocrats in the region often overlook the valuable insights that may be derived from the activities of AICs. A secularised approach to developmental issues is dominant, and the role of religious communities is often understated. While the continent is awash with religion, most deliberations on the future of the continent proceed without the faintest reference to spirituality. Perhaps this is due to the belief that religion stifles development or that it may be too divisive. In the following section, I argue for the continued relevance of spirituality to African development. I maintain that spirituality is an important resource that has been overlooked in discourses on Africa's reawakening. Spirituality could play an important role in the quest for regional integration.

\section{Spirituality in Southern Africa: A Forgotten Resource?}

While this study has highlighted the significance of AICs to the quest for regional integration, the NEPAD document (2001:42) devotes only a paragraph to the role of culture in the new dispensation. It is obvious that those who crafted this document have succumbed to the secularised view of reality. Perhaps they felt that it was embarrassing to include references to religion and culture in a document dealing with economic and technical issues. It could also be that they were convinced that Europe has attained high levels of economic development while adhering to a secular approach to life. However, I am convinced that such a perspective fails to appreciate the value of religion to African life.

Granted that Christianity, Islam and indigenous religions have not always been beneficial to Africans, it remains true that religion plays an important role on the continent. To ignore the religious dimension is to fail to approach homo Africanus in her entirety. As the discussion on the role of AICs in the informal sector shows, religion has a direct bearing on economic activities. By utilising the idea of African self-sufficiency, AICs have mobilised their members to undertake useful economic activities. It is therefore crucial for those who seek to achieve regional integration to pay attention to such initiatives by grassroots religious communities. 
The spirituality that characterises communities in Southern Africa was a significant factor during liberation struggles. By emphasising the right of Africans to lead wholesome lives, activists from various spiritual traditions actively participated in the quest for freedom. Religious texts from these traditions were interpreted in the context of human rights, as blacks fought for their rightful place. In Zimbabwe, some AIC prophets condemned the colonial regime for its naked racism and oppression. They encouraged blacks to subvert the economy by moving into the informal sector. In line with the indigenous African understanding of salvation, AICs preached the message of holistic liberation.

As policy planners in the region seek to consolidate the democratic renaissance, they should creatively appropriate progressive religious ideologies. The spiritual traditions that are dominant in Southern Africa can be utilised to promote human liberation (Cohn-Sherbok 1992). This will facilitate a more promising approach to development. It is religion that influences identity and commitment to ideals. Without fanning the flames of fanaticism, religion can be used to mobilise individuals and communities to strive for what they uphold.

As Africa positions herself to attain economic prosperity on the platform of unity and cooperation, the message of AIC prophets remains urgent and valuable. Long before the contemporary discourses on the African Renaissance, Paul Mwazha proclaimed the message of the "Recreation of Africa". In his 1940 vision, Mwazha was shown a united and economically independent Africa. He went on to preach about the need for Africans to achieve high academic standards for them to challenge Western dominance. Mwazha proclaimed that Africans should fight for religious and political emancipation. His prophetic pronouncements find resonance with the current calls for an African Renaissance (Chitando 2003: 248).

African spirituality can also be appropriated to equip the inhabitants of the region to persevere in the wake of the challenges that lie ahead. This study has already raised the threat of HIV/AIDS and how it has sapped the confidence of African communities. Faith-based organisations will be required to play an increasing role in HIV/AIDS prevention and care. AICs have been actively involved in this struggle, moving resources from one community to the other. Through their grassroots approach, AICs in the region have presented a formidable front in the fight against HIV/AIDS. 
Spirituality is a valuable resource that should be harnessed for regional integration and development. It can become a uniting factor for the diverse communities of Southern Africa. As the example of AICs illustrates, sharing a common religious ideology has facilitated the coming together of people with different backgrounds. Spirituality can help individuals and communities in the region to overcome potentially divisive identities. It is therefore incumbent upon African intellectuals to appreciate the value of spirituality to African life and to integrate it within their programmes.

\section{Conclusion}

In this study I have argued that AICs provide a helpful model to those who seek to forge unity and cooperation within the SADC region and on the continent. Emerging as "sites of struggle" during the colonial period, AICs have pressed for black liberation in all spheres of life. Furthermore, AICs have sought to transcend colonial boundaries, encouraging all Africans to work together for mutual benefits. AICs have therefore moved from rhetoric to action, facilitating the participation of their members in programmes meant to promote black economic empowerment. Adherents of AICs have formed regional support networks in their struggle for progress. I have also maintained that the quest for an African Renaissance may be enhanced by appropriating the important resource of spirituality. It is my firm conviction that AICs in Southern Africa have proudly marched ahead of policy planners and politicians and serve to impart valuable lessons to all those who pause to reflect on the role of grassroots communities in the proposed new Africa. These movements are spiritually grounded, economically astute and ideologically sophisticated: ingredients necessary for the rebirth of Africa.

\section{References}

Anderson, A., 2000, Zion and Pentecost: The Spirituality and Experience of Pentecostal and Zionist/Apostolic Churches, Pretoria: UNISA Press.

Chipeta, C., ed.,1998, Trade and Investment in Southern Africa: Towards Regional Economic Cooperation and Integration, Harare: SAPES Books.

Chirenje, J.M., 1987, Ethiopianism and Afro-Americans in Southern Africa, 1883-1916, Baton Rouge: Louisiana State University Press.

Chitando, E., 1998, "The Redeeming Memory: Reflections on Christianity and Black Economic Empowerment in Zimbabwe”, Missionalia 26(1), pp. 74-93.

Chitando, E., 2002, “'For We Have Heard for Ourselves?' A Critical Review of T. Ranger's Portrayal of Christianity as an African Religion”, Studia Historiae Ecclesiasticae 28(1), pp. 218-34. 
Chitando, E., 2003, "The Recreation of Africa: A Study of the Ideology of the African Apostolic Church of Zimbabwe”, Exchange 32(3), pp. 239-249.

Cohn-Sherbok, D., ed., 1992, World Religions and Human Liberation, Maryknoll, N.Y.: Orbis Books.

Corten, A. and Marshall-Fratani, R., eds., 2001, Between Babel and Pentecost: Transnational Pentecostalism in Africa and Latin America, Bloomington: Bloomington University Press

Cox, H., 1996, Fire From Heaven: The Rise of Pentecostal Christianity and the Reshaping of Religion in the Twenty-First Century, London: Cassell.

Daneel, I., 1987, Quest for Belonging: Introduction to a Study of African Independent Churches, Gweru: Mambo Press.

Dillon-Malone, C. M., 1978, The Korsten Basketmakers: A Study of the Masowe Apostles, an Indigenous African Religious Movement, Manchester: Manchester Univ. Press.

Gaidzanwa, R.B., 1998, "Cross-Border Trade in Africa: A Gendered Perspective", in Lloyd Sachikonye, ed., Labour and Migration in Southern Africa, 83-94, Harare: SAPES Books.

Hackett, R.I.J., 1995, "Women and New Religious Movements in Africa”, in Ursula King, ed., Religion and Gender, pp. 257-290, Oxford: Blackwell.

Hadland, A. and J. Rantao, 1999, The Life and Times of Thabo Mbeki, Rivonia: Zebra Press.

Isichei, E., 1995, A History of Christianity in Africa from Antiquity to the Present, London: SPCK

Kalu, O.U., 2000, Power, Poverty and Prayer: The Challenges of Poverty and Pluralism in African Christianity, 1960-1996, Frankfurt am Main: Peter Lang.

Matlosa, K., ed., 2001, Migration and Development in Southern Africa: Policy Reflections, Harare: SAPES Books.

Maxwell, D., 2002, "Christianity without Frontiers: Shona Missionaries and Transnational Pentecostalism in Africa”, in David Maxwell and Ingrid Lawrie, eds., Christianity and the African Imagination: Essays in Honour of Adrian Hastings, pp. 295-332, Leiden: Brill.

Mugabe, R.G., 2001, Inside the Third Chimurenga: Our Land is Our Prosperity, Harare: Department of Information and Publicity, Office of the President and Cabinet.

Muzvidziwa, V. N., 1998, Urban Women's Strategies to Deal with Impoverishment in Masvingo, Zimbabwe, Unpublished PhD thesis, University of Wiakato.

New Partnership for Africa's Development (NEPAD), 2001, Abuja.

Okeyere-Manu, B., 2003, "Hope in a Time of AIDS", International Congregational Journal 3(2), pp.169-183.

Oosthuizen, G., 1992, "Development in the Traditional African and Afro-Christian Context with Special Reference to Mutual Aid Societies and Small-Scale Businesses", in Renier Koegelenberg, ed., Church and Development, An Interdisciplinary Approach: Perspectives from Southern Africa and Europe, pp.254-290, Bellville: EFSA-Institute for Theological and Interdisciplinary Research.

Sachikonye, L., ed., 1998, Labour and Migration in Southern Africa, Harare: SAPES Books.

Walsh, T. G. and Kaufmann, F., eds., 1999, Religion and Social Transformation in Southern Africa, St Paul, Minnesota: Paragon House. 